\title{
Effect of polymorphisms in the leptin, leptin receptor, and acyl-coenzyme A:diacylglycerol acyltransferase 1 (DGAT1) genes and genetic polymorphism of milk proteins on cheese characteristics
}

\author{
M. Glantz, ${ }^{* 1}$ H. Lindmark Månsson, ${ }^{*} †$ H. Stålhammar, $\neq$ and M. Paulsson ${ }^{*}$ \\ *Department of Food Technology, Engineering and Nutrition, Lund University, PO Box 124, SE-221 00 Lund, Sweden \\ †Swedish Dairy Association, Ideon Science Park, SE-223 70 Lund, Sweden \\ ¥VikingGenetics, PO Box 64, SE-532 21 Skara, Sweden
}

\begin{abstract}
Cheese production has increased worldwide during the last decade and is expected to increase within the coming decade as well. Despite this, the relations between cow genetics and cheese characteristics are not fully known. The aim of this study was to determine if polymorphisms in the leptin $(L E P)$, leptin receptor $(L E P R)$, and acyl-coenzyme A:diacylglycerol acyltransferase 1 (DGAT1) genes as well as genetic variants of $\beta$-casein $(\beta-\mathrm{CN}), \kappa-\mathrm{CN}$, and $\beta$-lactoglobulin $(\beta-\mathrm{LG})$ affect technological properties important for cheese production and, hence, could act as genetic makers for cheese quality. Individual milk samples from the Swedish Red and the Swedish Holstein breeds were analyzed for sizes of $\mathrm{CN}$ micelles and fat globules as well as rennet-induced gel strength, gelation time, and yield stress. Model cheeses were produced to study yield, hardness, and $\mathrm{pH}$ of the cheeses. The A1457G, A252T, $\mathrm{A} 59 \mathrm{~V}$, and C963T single nucleotide polymorphisms (SNP) were analyzed on the $L E P$ gene, the T945M SNP on the $L E P R$ gene, and the Nt984+8(A-G) SNP on the DGAT1 gene. In addition, genetic variants of $\beta-\mathrm{CN}, \kappa-\mathrm{CN}$, and $\beta-\mathrm{LG}$ were determined. The results indicate that technological properties were influenced by the $\mathrm{LEPR}_{\mathrm{T} 945 \mathrm{M}}$ polymorphism, which had an association with gel strength, yield stress, and cheese hardness $(T>C)$. However, also $\operatorname{LEP}_{\mathrm{A} 252 \mathrm{~T}}$ was shown to affect gel strength $(T>\mathrm{A})$, whereas the $\mathrm{LEP}_{\mathrm{A} 59 \mathrm{~V}}$ had an effect on fat globule size $(T>C)$. For the milk protein genes, favorable effects were found for the A and $\mathrm{B}$ variants of $\beta-\mathrm{LG}$ and $\kappa-\mathrm{CN}$, respectively, on gel strength, gelation time, and yield stress. In addition, the $\mathrm{B}$ variant of $\kappa-\mathrm{CN}$ was shown to be associated with smaller CN micelles than the A variant. Thus, the results demonstrate potential genetic markers for cheese characteristics. However, milk composition traits also affected the obtained results, thus making it necessary to thoroughly assess the different aspects regarding the
\end{abstract}

Received February 28, 2011.

Accepted April 15, 2011.

${ }^{1}$ Corresponding author: maria.glantz@food.lth.se influence of gene effects on cheese characteristics before directly selecting for certain alleles or genetic variants to improve the processing and quality of cheese.

Key words: leptin, milk protein polymorphism, milk gelation, cheese

\section{INTRODUCTION}

Recently, several studies have been done on singlegene effects on milk composition traits, to find markers that can be used in genetic selection programs to improve milk quality (e.g., Schennink et al., 2007; Banos et al., 2008; Barbosa da Silva et al., 2010). Even though cheese production has increased worldwide during the last decade and is expected to increase within the coming decade as well (International Dairy Federation, 2010), the relations between cow genetics and cheese characteristics are only partly known, especially for milk protein genes. Thus far, studies have focused on milk protein genes, such as $\beta-\mathrm{CN}, \kappa-\mathrm{CN}$, and $\beta-\mathrm{LG}$, and their effects on cheese properties (Buchberger and Dovc, 2000; Wedholm et al., 2006; Hallén et al., 2007). However, other genes also have the potential to act as genetic markers for cheese characteristics. Despite this, no attempt has yet been made to explore this.

Genetic polymorphism of milk proteins has been shown to affect milk gelation and cheese yield (reviewed by Jakob and Puhan, 1992; Ng-Kwai-Hang, 1998; and Buchberger and Dovc, 2000); however, the results are sometimes contradictory. The most consistent findings concern $\kappa-\mathrm{CN}$. It has been shown that $\kappa-\mathrm{CN} B$ is associated with shorter coagulation time and firmer curd (Ng-Kwai-Hang, 1998; Ikonen et al., 1999; Wedholm et al., 2006), as well as higher cheese yield (Jakob and Puhan, 1992; Ng-Kwai-Hang, 1998; Wedholm et al., 2006) than $\kappa-\mathrm{CN} \mathrm{A}$, and the $\mathrm{E}$ variant of $\kappa-\mathrm{CN}$ has been shown to negatively affect gelation properties (Ikonen et al., 1999; Wedholm et al., 2006; Hallén et al., 2007). The A1A2 genotype of $\beta-\mathrm{CN}$ has been shown to increase curd firmness (Ikonen et al., 1997; Hallén et al., 2007), whereas the A2A2 genotype has been reported to be associated with less favorable gelation properties (Lodes et al., 1996; Hallén et al., 2007). In contrast, 
studies have shown no effect of the $\beta$-CN genotype on curd firmness (Lodes et al., 1996) or gelation time (Pagnacco and Caroli, 1987; Ikonen et al., 1997). Furthermore, $\beta-\mathrm{CN}$ A1A1 has been shown to be associated with higher cheese yield than the A1A2 genotype (Marziali and $\mathrm{Ng}$-Kwai-Hang, 1986a,c). Even though $\beta$-LG itself is not part of the rennet-induced gelation process, studies have shown that genetic variants of this protein affect gelation properties. $\beta$-Lactoglobulin AA has been reported to have shorter gelation time and form a firmer curd than $\beta$-LG BB (Marziali and Ng-Kwai-Hang, 1986b; Choi, 1996), whereas some only found an effect on gelation time (Ikonen et al., 1999; Kübarsepp et al., 2005; Bonfatti et al., 2010) or curd firmness (Andrén, 2007) for this genotype. However, Lodes et al. (1996) found a favorable effect of $\beta-\mathrm{LG} \mathrm{BB}$ on curd firmness. In contrast to these findings, Pagnacco and Caroli (1987), Ikonen et al. (1997), and Hallén et al. (2007) found no effect of $\beta$-LG on milk gelation properties. More consistent is the findings for cheese yield, where $\beta-L G$ B has been shown to give higher yield than the A variant (Jakob and Puhan, 1992; Ng-Kwai-Hang, 1998; Wedholm et al., 2006).

During the past years, research has been able to reveal potential genetic markers for milk composition traits. The leptin $(\boldsymbol{L E P})$, leptin receptor $(\boldsymbol{L} \boldsymbol{E P R})$, and acyl-coenzyme A:diacylglycerol acyltransferase 1 (DGAT1) genes are some examples that have been shown to affect milk composition (Komisarek and Dorynek, 2006; Schennink et al., 2007; Banos et al., 2008). An earlier study (our unpublished data) showed that polymorphisms in the $L E P$ and $L E P R$ genes have an effect on, among others, protein content, total and ionic $\mathrm{Ca}$, and milk $\mathrm{pH}$, which all have been shown to affect milk gelation (Amenu and Deeth, 2007; Glantz et al., 2010). Thus, it is of great interest to examine the effects of these genes on technological properties important for cheese production, to find more markers for cheese characteristics and, hence, have the possibility of direct selection of cheese quality within the breeding work. In this study, technological properties important for cheese production, such as gel strength, gelation time, cheese yield and texture, and sizes of $\mathrm{CN}$ micelles and fat globules, were examined. The aim was to determine if polymorphisms in the LEP, LEPR, and DGAT1 genes as well as genetic variants of $\beta-\mathrm{CN}$, $\kappa-\mathrm{CN}$, and $\beta-L G$ affect these technological properties and, hence, could act as genetic markers for cheese quality.

\section{MATERIALS AND METHODS}

\section{Animals}

A total of 20 cows from the research farm Nötcenter Viken (Falköping, Sweden), whereof 10 cows were of the Swedish Holstein (SH) breed and 10 cows were of the Swedish Red (SR) breed, were selected based on milk production and sampled at one sampling occasion in September 2008 for morning milk, blood, and hair root samples. An integrated part of the Swedish breeding occurs at this research farm, which has a unique nucleus breeding herd producing a large number of bull dams. Cows were descended from $7 \mathrm{SH}$ and $5 \mathrm{SR}$ proven bulls, respectively. The cows were in the second lactation, healthy, fed the same diet, and milked 3 times per day. To exclude extremes in the beginning of the lactation, the cows were in lactation wk 8 to 50 . At the time of sampling, the cows had been fed in the stable for several weeks and been adjusted to the winter feeding regimen.

\section{Technological Properties}

Rheological Measurements. Rennet-induced gelation was carried out at $32^{\circ} \mathrm{C}$ for $40 \mathrm{~min}$ as described earlier (Glantz et al., 2009) with low-amplitude oscillation measurements (Stresstech rheometer; Reologica Instruments AB, Lund, Sweden) using chymosin (0.90 $\mathrm{mL} / \mathrm{L}$ of Chy-Max Plus, 200 international milk clotting U/mL; Christian Hansen A/S, Hørsholm, Denmark) to determine gel strength and gelation time on fresh milk samples defatted by centrifugation at $2000 \times g$ for 30 min. The method was somewhat modified: $30 \mathrm{~mL}$ of skim milk was used and the geometry of the instrument was a smooth cup (27 $\mathrm{mm}$ in diameter) and 4-bladed vane (21 $\mathrm{mm}$ in diameter and $45 \mathrm{~mm}$ in height). The gap was set at $2 \mathrm{~mm}$. Gel strength was defined as the elastic or storage modulus, $\mathrm{G}^{\prime}$, after $40 \mathrm{~min}$ gelation, where $\mathrm{G}^{\prime}=\sigma_{0} / \gamma_{0} \cdot \cos \delta$, and gelation time was defined as $\mathrm{G}^{\prime \prime}=\mathrm{G}^{\prime}$, where $\mathrm{G}^{\prime \prime}=\sigma_{0} / \gamma_{0} \cdot \sin \delta\left(\sigma_{0}=\right.$ maximum stress; $\gamma_{0}=$ maximum shear strain; $\delta=$ phase angle, phase difference between the strain and stress). The values of gel elasticity of the developing gel that was obtained with the vane geometry were recalculated to values that would be obtained with a normal CC25 bob (25 $\mathrm{mm}$ in diameter) using a calibration curve. Following gel formation, stress sweeps were run to study the stress dependence of the viscosity to obtain the yield stress. The shear stress was increased in 100 intervals from 0.1 to $300 \mathrm{~Pa}$. The yield stress was defined as the shear stress at the first local maximum of the viscosity. The samples were analyzed at least in duplicate.

Cheese Characteristics. To decrease the number of variables influencing cheese characteristics, model cheeses were produced from skim milk. Two hundred and fifty milliliters of skim milk was pasteurized in a water bath at $72^{\circ} \mathrm{C}$ for $15 \mathrm{~s}$ (Wedholm et al., 2006) and $3.76 \mathrm{~g} / \mathrm{kg}$ of glucano- $\delta$-lactone (Roquette Frères, Lestrem Cedex, France; Lucey et al., 1997) and 1.25 
$\mathrm{mL} / \mathrm{L}$ of chymosin (Chy-Max Plus, 200 international milk clotting $\mathrm{U} / \mathrm{mL}$; Christian Hansen $\mathrm{A} / \mathrm{S}$ ) were added before the mixture was gently stirred. The mixture was left at $32^{\circ} \mathrm{C}$ for $35 \mathrm{~min}$ before the gel formed was cut into 2 -cm cubes. The curd was incubated at $50^{\circ} \mathrm{C}$ for 30 min to allow syneresis. Whey was removed and the curd was pressed $\left(0.01 \mathrm{~kg} / \mathrm{cm}^{2}\right)$ during $20 \mathrm{~h}$ at room temperature. The cheeses were stored at $12^{\circ} \mathrm{C}$ for $1 \mathrm{wk}$ before they were weighed to obtain the yield (expressed as $g$ of cheese $/ 100 \mathrm{~g}$ of milk) and analyzed for cheese $\mathrm{pH}$ and hardness. The cheeses were cut into small cubes and water was added in the same amount as the cheese weight, before $\mathrm{pH}$ was measured at room temperature on the cheeses. One batch of cheese was made for each sample.

Cylindrical cheeses $(17 \mathrm{~mm}$ in height and $22 \mathrm{~mm}$ in diameter) were uniaxially compressed at $12^{\circ} \mathrm{C}$ to $80 \%$ of the original height (Dimitreli and Thomareis, 2007), with 2 subsequent cycles of compression-decompression, using a TA-XT2i texture analyzer (Stable Micro Systems Ltd., Godalming, UK) to obtain cheese hardness. The system was equipped with a load cell $(5 \mathrm{~kg})$ and a probe $(25 \mathrm{~mm}$ in diameter and $36 \mathrm{~mm}$ in length) and the pre-test speed, test speed, and post-test speed was set at $2 \mathrm{~mm} / \mathrm{s}$. For each batch of cheese, triplicate measurements were made.

Size Determination of CN Micelles and Fat Globules. The z-average hydrodynamic diameter of $\mathrm{CN}$ micelles was determined at $25^{\circ} \mathrm{C}$ and a scattering angle of $90^{\circ}$ on skim milks diluted in simulated milk ultrafiltrate (Jenness and Koops, 1962) by using photon correlation spectroscopy (Zetasizer 3000HS; Malvern Instruments Ltd., Malvern, UK), as described by Glantz et al. (2010). All samples were analyzed in triplicate. The volume-weighted droplet diameter, $\mathrm{d}(4,3)$, of fat globules was determined according to Glantz et al. (2009) at $20^{\circ} \mathrm{C}$ on fresh milk samples by using light diffraction (Coulter LS 130; Beckman Coulter Inc., High Wycombe, UK). Duplicate measurements were made on each sample.

\section{Milk Composition}

Data on contents of protein, CN, whey proteins, nonprotein nitrogen, lipid, lactose, $\mathrm{Ca}$, and $\mathrm{P}$, as well as free $\mathrm{Ca}^{2+}$ concentrations at 25 and $32^{\circ} \mathrm{C}$, fatty acid (FA) composition, SCC, freezing point, and $\mathrm{pH}$ were used to obtain correlations between technological properties and milk composition traits (our unpublished data). In brief, the contents of protein, lipid, and lactose, as well as freezing point, were analyzed by using an infrared technique; the contents of $\mathrm{CN}$, whey proteins, and nonprotein nitrogen were determined by using the Kjeldahl method; the contents of $\mathrm{Ca}$ and $\mathrm{P}$ were analyzed with inductively coupled plasma mass spectrometry; the FA composition was determined with GC; and somatic cells were analyzed with flow cytometry (Glantz et al., 2009). In addition, the milk yield of the whole sampling day (the total of 3 milkings) was recorded for each cow and yields per cow per day of the components were calculated by multiplying each percentage by the milk yield.

Concentrations of free $\mathrm{Ca}^{2+}$ were analyzed at 25 and $32^{\circ} \mathrm{C}$ with a $\mathrm{Ca}$ electrode (Orion 97-20 Ionplus Calcium Electrode; Thermo Electron Corp., Beverly, MA) in skim milk samples. Before analysis, $22.5 \mathrm{~mL}$ of skim milk and $0.45 \mathrm{~mL}$ of $\mathrm{Ca}$ ionic strength adjuster (Thermo Fisher Scientific Inc., Beverly, MA) were mixed and preheated to 25 and $32^{\circ} \mathrm{C}$, respectively, in a water bath. Calibration of the electrode was performed according to the manufacturer's instruction. To convert the measured electrode potential $(\mathrm{mV})$ to $\mathrm{Ca}^{2+}$ concentration $(\mathrm{m} M)$, calibration curves at 25 and $32^{\circ} \mathrm{C}$ were obtained by using standard solutions of 0.1 to $10 \mathrm{mM}$ $\mathrm{CaCl}_{2}$ (Thermo Electron Corp.).

\section{Genetic Analyses}

In brief, DNA was extracted from hair root samples and genotypes and alleles at the LEP, LEPR, and $D G A T 1$ gene loci were determined using allele-specific primer extension reactions analyzed with matrix-assisted laser desportion/ionization time-of-flight mass spectrometry. The following 6 SNP were analyzed: A1457G and $\mathrm{C} 963 \mathrm{~T}$ in the $L E P$ promoter region, A252T and $\mathrm{A} 59 \mathrm{~V}$ in the $L E P$ exon 2 and 3 regions, respectively, T945M in the $L E P R$ exon 20 region, and Nt984+8(A$\mathrm{G})$ in the DGAT1 exon 12 region. The genetic analyses were performed by Igenity (Harlow, UK).

In addition to the above-mentioned polymorphisms, genetic variants of $\beta-\mathrm{CN}(\mathrm{A} 1, \mathrm{~A} 2), \kappa-\mathrm{CN}(\mathrm{A}, \mathrm{B}, \mathrm{E})$, and $\beta$-LG (A, B) were determined in blood samples with PCR-based methods. The analyses were preformed by Dr. Van Haeringen Laboratorium b.v. (Wageningen, the Netherlands).

\section{Statistical Analyses}

Univariate models were used to evaluate the effects of polymorphisms and genetic variants of milk proteins on technological properties of milk. Least squares means and standard errors were determined using the general linear model procedure from Minitab (version 14; Minitab Ltd., Coventry, UK) as well as pairwise testing of significant differences in alleles. The following model is based on the selection criteria and was used to analyze data for the $L E P, L E P R$, and DGAT1 genes:

$$
\begin{aligned}
y_{i j k}= & \mu+\text { breed }_{i}+\text { milk volume }_{j} \\
& +{\text { gene } \text { allele }_{k}+\varepsilon_{i j k},}
\end{aligned}
$$


where $y_{i j k}=$ technological property; $\mu=$ general mean; breed $_{i}=$ fixed effect of breed $(i=\mathrm{SR}$ or $\mathrm{SH}) ;$ milk volume $_{j}=$ fixed effect of milk production $(j=10$ to 20 $\mathrm{kg}, 21$ to $30 \mathrm{~kg}$, or $>30 \mathrm{~kg}$ ); gene allele $e_{k}=$ fixed effect of gene allele $\left(k=\mathrm{LEP}_{\mathrm{A} 1457 \mathrm{G}} \mathrm{A}\right.$ or $\mathrm{G} ; \mathrm{LEP}_{\mathrm{A} 252 \mathrm{~T}} \mathrm{~A}$ or $\mathrm{T}$; $\mathrm{LEP}_{\mathrm{A} 59 \mathrm{~V}} \mathrm{C}$ or $\mathrm{T} ; \mathrm{LEP}_{\mathrm{C} 963 \mathrm{~T}} \mathrm{C}$ or T; $\mathrm{LEPR}_{\mathrm{T} 945 \mathrm{M}} \mathrm{C}$ or T; $\mathrm{DGAT}_{\mathrm{Nt} 984+8(\mathrm{~A}-\mathrm{G})} \mathrm{A}$ or $\left.\mathrm{G}\right)$; and $\varepsilon_{i j k}=$ random residual effect. A fixed effect of lactation stage and interactions have been analyzed but were not significant and were, therefore, excluded from the statistical model.

For the genetic variants of milk proteins, a multigene model was used to consider that the alleles of the different $\mathrm{CN}$ are in linkage disequilibrium (Bovenhuis et al., 1992). The following model was, therefore, used:

$$
\begin{aligned}
y_{i j k l m} & =\mu+\text { breed }_{i}+\text { milk }_{\text {volume }}+\beta-C N \text { allele }_{k} \\
& +\kappa-C N \text { allele }_{l}+\beta-L G \text { allele }_{m}+\varepsilon_{i j k l m},
\end{aligned}
$$

where $y_{i j k l m}=$ technological property; $\mu=$ general mean; breed $_{i}=$ fixed effect of breed $(i=\mathrm{SR}$ or $\mathrm{SH})$; milk volume $_{j}=$ fixed effect of milk production $(j=10$ to $20 \mathrm{~kg}, 21$ to $30 \mathrm{~kg}$, or $>30 \mathrm{~kg}$ ); $\beta$-CN allele $_{k}=$ fixed effect of $\beta$-CN allele $(k=\mathrm{A} 1$ or $\mathrm{A} 2) ; \kappa-C N$ allele $_{l}=$ fixed effect of $\kappa$-CN allele $(l=\mathrm{A}, \mathrm{B}$, or $\mathrm{E}) ; \beta-L G$ allele $e_{m}$ $=$ fixed effect of $\beta-\mathrm{LG}$ allele $(m=\mathrm{A}$ or $\mathrm{B})$; and $\varepsilon_{i j k l m}$ $=$ random residual effect. A fixed effect of lactation stage and interactions have been analyzed but were not significant and were, therefore, excluded from the statistical model.

The Pearson correlation coefficient was calculated using Minitab (version 14; Minitab Ltd.) to estimate linear correlations between technological properties and milk composition traits. The level of significance was set at $P<0.05$.

\section{RESULTS AND DISCUSSION}

\section{Means and Variation}

Mean values, standard deviations, and coefficients of variation of the analyzed technological properties are presented in Table 1. In the current study, a limited number of cows were used because of the numerous properties analyzed and the costs related to this. Despite this, the results obtained were in the range to be expected. The large standard deviations for gel strength and gelation time for SR were due to 2 of the 10 samples coagulating poorly, having a gel strength less than $0.5 \mathrm{~Pa}$ after $40 \mathrm{~min}$ of gelation. The gelation time observed for $\mathrm{SH}$ was in the range found previously in bulk milk (Glantz et al., 2009). The values obtained for cheese yield in this study were in the range reported earlier (Wedholm et al., 2006), as well as those for cheese pH (Dimitreli and Thomareis, 2007). Further- more, $\mathrm{CN}$ micelle sizes were in the ranges previously found in bulk milk and milk of individual cows (Devold et al., 2000; Glantz et al., 2010), and the same was true for the observed fat globule sizes (Glantz et al., 2009). The coefficients of variation were high $(>30 \%)$ for gelation properties and cheese hardness, whereas for cheese yield, cheese $\mathrm{pH}$, and sizes of $\mathrm{CN}$ micelles and fat globules the coefficients of variation were low or moderate (ranging from 4 to 18\%). No breed difference was observed in this sample material for any of the properties.

\section{Effects of Polymorphisms in the LEP, LEPR, and DGAT1 Genes on Cheese Characteristics}

The allele frequencies estimated for the SNP within the $L E P, L E P R$, and DGAT1 genes showed the same tendency of minor allele frequency for all SNP, except on $\mathrm{LEP}_{\mathrm{A} 1457 \mathrm{G}}$ and $\mathrm{LEP}_{\mathrm{C} 963 \mathrm{~T}}$, for both the breeds (data not shown). Effects of polymorphisms in the $L E P$, $L E P R$, and DGAT1 genes on technological properties are given in Table 2. Results are shown only for (1) SNP that had an effect $(P<0.10)$ on at least one technological property and (2) properties that were significantly $(P<0.10)$ influenced by the studied SNP. The level of significance was set at $P<0.10$ because of the small sample number. As can be seen in Table 2 , results indicate that the $\mathrm{LEP}_{\mathrm{A} 252 \mathrm{~T}}, \mathrm{LEP}_{\mathrm{A} 59 \mathrm{~V}}$, and $\mathrm{LEPR}_{\mathrm{T} 945 \mathrm{M}}$ polymorphisms were associated with some of the studied technological properties. To our knowledge, this is the first time this has been reported. Of these, $\mathrm{LEPR}_{\mathrm{T} 945 \mathrm{M}}$ was shown to affect most properties. The results indicate that the $T$ allele of $L_{E P R}$ T945M was associated with higher gel strength, yield stress, and cheese hardness than the $\mathrm{C}$ allele, and the reliability of the estimates for these properties increased 2 to $11 \%$. In an earlier study (our unpublished data) we described an effect of this polymorphism on ionic $\mathrm{Ca}$ and milk $\mathrm{pH}$, where the $\mathrm{T}$ allele was shown to increase ionic $\mathrm{Ca}$ concentration at both 25 and $32^{\circ} \mathrm{C}$ and decrease milk pH. Studies have shown that gel strength increases with increased ionic Ca concentration (Tsioulpas et al., 2007) and decreased milk pH (Glantz et al., 2010). Thus, it can be concluded that the $\mathrm{T}$ allele of $\mathrm{LEPR}_{\mathrm{T} 945 \mathrm{M}}$ seems to favor gelation properties and cheese quality, and hence, that this polymorphism has the potential to act as genetic marker for both direct and indirect selection of cheese characteristics within a breeding program. The $\mathrm{LEP}_{\mathrm{A} 252 \mathrm{~T}}$ polymorphism was found to affect gel strength, where the $\mathrm{T}$ allele is associated with higher gel strength. Furthermore, the incorporation of milk fat globules in the $\mathrm{CN}$ gel and the milk fat globule size determine the microstructure as well as the ripening and consistency of the cheese 
Table 1. Unadjusted means, standard deviations, and coefficients of variation of technological properties of milk from the Swedish Red and Swedish Holstein breeds $(\mathrm{n}=10$ for each breed)

\begin{tabular}{|c|c|c|c|c|c|}
\hline \multirow[b]{2}{*}{ Property } & \multicolumn{2}{|c|}{ Swedish Red } & \multicolumn{2}{|c|}{ Swedish Holstein } & \multirow[b]{2}{*}{$P$-value } \\
\hline & $\begin{array}{l}\text { Mean } \\
\text { (SD) }\end{array}$ & $\begin{array}{l}\mathrm{CV} \\
(\%)\end{array}$ & $\begin{array}{l}\text { Mean } \\
\text { (SD) }\end{array}$ & $\begin{array}{l}\mathrm{CV} \\
(\%)\end{array}$ & \\
\hline Gel strength $(\mathrm{Pa})$ & $93(77)$ & 83 & $102(59)$ & 58 & 0.766 \\
\hline Gelation time (min) & $16.0(14.4)$ & 90 & $7.2(5.3)$ & 74 & 0.087 \\
\hline Yield stress $(\mathrm{Pa})$ & $21(14)$ & 67 & $22(8)$ & 36 & 0.888 \\
\hline Cheese $\mathrm{pH}$ & $6.12(0.31)$ & 5 & $6.06(0.23)$ & 4 & 0.636 \\
\hline Cheese yield (\%) & $7.7(1.0)$ & 13 & $7.3(1.3)$ & 18 & 0.412 \\
\hline Cheese hardness $(\mathrm{N})$ & $12.4(5.9)$ & 48 & $11.7(3.5)$ & 30 & 0.750 \\
\hline $\mathrm{CN}$ micelle size (nm) & $172(21)$ & 12 & $173(16)$ & 9 & 0.849 \\
\hline Fat globule size $(\mu \mathrm{m})$ & $3.9(0.2)$ & 5 & $3.7(0.4)$ & 11 & 0.321 \\
\hline
\end{tabular}

(Walstra et al., 1999). The LEP $_{\text {A59v }}$ polymorphism was shown to have an effect on fat globule size and, hence, the results indicate the possibility of controlling the size of fat globules within genetic selection programs. For the $\mathrm{LEP}_{\mathrm{A} 252 \mathrm{~T}}$ and $\mathrm{LEP}_{\mathrm{A} 59 \mathrm{~V}}$ polymorphisms, the reliability of the estimates for the properties increased 6 and $13 \%$, respectively. However, no significant $(P<0.10)$ effect of the $\mathrm{LEP}_{\mathrm{A} 1457 \mathrm{G}}, \mathrm{LEP}_{\mathrm{C} 963 \mathrm{~T}}$, or DGAT1 $1_{\mathrm{Nt} 984+8(\mathrm{~A}-\mathrm{G})}$ polymorphisms was found on any of the analyzed technological properties.

\section{Effects of Alleles of $\beta-C N, k-C N$, and $\beta-L G$ on Cheese Characteristics}

As for the $L E P, L E P R$, and DGAT1 genes, the same tendency of minor allele frequency was found for all of the analyzed milk protein genes for both breeds (data not shown). Table 3 shows effects of $\beta-\mathrm{CN}, \kappa-\mathrm{CN}$, and $\beta$-LG alleles on technological properties. Once again, results are shown only for (1) proteins that had an effect $(P<0.10)$ on at least one technological property and $(2)$ properties that were significantly $(P<0.10)$ influenced by the studied milk protein genes. The level of significance was set at $P<0.10$ because of the small sample number. The results show that $\kappa-\mathrm{CN}$ and $\beta-\mathrm{LG}$ were associated with technological properties of milk; however, no associations were found for $\beta$-CN. The A variant of $\beta$-LG was shown to give higher gel strength, shorter gelation time, and higher yield stress than the B variant. One explanation for this may be the difference in $\mathrm{AA}$ sequence between the 2 variants. The $\mathrm{A}$ and $\mathrm{B}$ variants differ at 2 positions in the sequence, Asp64Gly and Val118Ala, respectively (Edwards et al., 2009). This would result in different conformations of the 2 protein variants, which may have yielded the obtained results. Another explanation could be that the dissociation constant is higher for the $\mathrm{A}$ variant than the $\mathrm{B}$ variant, and hence, the $\mathrm{A}$ variant will have a higher aggregation rate (Elofsson et al., 1996). In the processing of cheese, whey proteins and most of the lactose are generally lost in the whey. Despite this, the results indicated that $\beta$-LG influences gelation properties. $\beta$-Lactoglobulin has also been identified in hard cheeses using reversed-phase HPLC (Rehn et al., 2010). The results obtained in this study have been reported earlier for both gel strength and gelation time by Marziali and Ng-Kwai-Hang (1986b) and Choi (1996), but only for gelation time by Ikonen et al. (1999), Kübarsepp et al.

Table 2. Effects of leptin $(L E P)$ and leptin receptor $(L E P R)$ alleles on technological properties of milk ${ }^{1}$

\begin{tabular}{|c|c|c|c|}
\hline \multirow{2}{*}{$\frac{\text { Item }}{\mathrm{LEP}_{\mathrm{A} 252 \mathrm{~T}}}$} & \multicolumn{2}{|c|}{ Allele } & \multirow[t]{2}{*}{$P$-value } \\
\hline & $\mathrm{A}$ & $\mathrm{T}$ & \\
\hline Gel strength $(\mathrm{Pa})$ & $80 \pm 13$ & $132 \pm 25$ & 0.079 \\
\hline $\mathrm{LEP}_{\mathrm{A} 59 \mathrm{~V}}$ & $\mathrm{C}$ & $\mathrm{T}$ & \\
\hline Fat globule size $(\mu \mathrm{m})$ & $3.7 \pm 0.1$ & $4.0 \pm 0.1$ & 0.013 \\
\hline $\mathrm{LEPR}_{\mathrm{T945M}}$ & $\mathrm{C}$ & $\mathrm{T}$ & \\
\hline Gel strength $(\mathrm{Pa})$ & $82 \pm 12$ & $159 \pm 31$ & 0.023 \\
\hline Yield stress $(\mathrm{Pa})$ & $19 \pm 2$ & $30 \pm 5$ & 0.047 \\
\hline Cheese hardness (N) & $11.4 \pm 0.9$ & $16.4 \pm 2.3$ & 0.048 \\
\hline
\end{tabular}


Table 3. Effects of $\beta$-LG and $\kappa-\mathrm{CN}$ alleles on technological properties of milk ${ }^{1}$

\begin{tabular}{|c|c|c|c|c|}
\hline Item & & Allele & & $P$-value \\
\hline$\beta-L G$ & $\mathrm{~A}$ & $\mathrm{~B}$ & & \\
\hline Gel strength $(\mathrm{Pa})$ & $115 \pm 13$ & $61 \pm 17$ & & 0.011 \\
\hline Gelation time (min) & $6.9 \pm 2.2$ & $17.3 \pm 2.8$ & & 0.004 \\
\hline Yield stress $(\mathrm{Pa})$ & $24 \pm 2$ & $16 \pm 3$ & & 0.022 \\
\hline$\kappa-\mathrm{CN}$ & $\mathrm{A}$ & $\mathrm{B}$ & $\mathrm{E}$ & \\
\hline Gel strength $(\mathrm{Pa})$ & $51^{\mathrm{a}} \pm 16$ & $118^{\mathrm{b}} \pm 19$ & $95^{\mathrm{ab}} \pm 22$ & 0.013 \\
\hline Gelation time (min) & $18.3^{\mathrm{a}} \pm 2.6$ & $\begin{array}{l}110 \\
8.1^{\mathrm{b}} \pm 3.1\end{array}$ & $9.8^{\mathrm{ab}} \pm 3.6$ & 0.019 \\
\hline Yield stress $(\mathrm{Pa})$ & $15^{\mathrm{a}} \pm 3$ & $25^{\mathrm{b}} \pm 3$ & $21^{\mathrm{ab}} \pm 4$ & 0.038 \\
\hline CN micelle size (nm) & $181^{\mathrm{a}} \pm 5$ & $160^{\mathrm{b}} \pm 6$ & $175^{\mathrm{ab}} \pm 6$ & 0.006 \\
\hline
\end{tabular}

(2005), and Bonfatti et al. (2010) or gel strength by Andrén (2007). However, other studies have indicated contradictory results (Lodes et al., 1996) or no association at all with gelation properties (Pagnacco and Caroli, 1987; Ikonen et al., 1997; Hallén et al., 2007). Thus, selecting for a specific genetic variant of $\beta$-LG may affect cheese characteristics negatively, and hence, more studies are needed before this protein can act as a genetic marker in genetic selection programs.

The $\mathrm{B}$ variant of $\kappa$-CN was shown to give higher gel strength, shorter gelation time, higher yield stress, and smaller native CN micelles than the A variant. Similar results have been reported earlier for gel strength and gelation time (Ng-Kwai-Hang, 1998; Ikonen et al., 1999;
Wedholm et al., 2006). Studies have shown that smaller native CN micelles form stronger rennet-induced gels for well-coagulating milk (Amenu and Deeth, 2007; Glantz et al., 2010). Thus, all of the influenced properties conform with the characteristics of a good gel, and hence, it can be concluded that the B variant of $\kappa$ - CN seems to favor gelation properties. However, no significant $(P<0.10)$ association was found between $\kappa-\mathrm{CN}$ and cheese yield in this study, which has been reported earlier (Jakob and Puhan, 1992; Ng-Kwai-Hang, 1998; Wedholm et al., 2006). Intermediate gelation properties were found for $\kappa-\mathrm{CN} \mathrm{E}$ and no significant $(P<0.05)$ differences could be found between the $\mathrm{E}$ variant and $\mathrm{A}$ and $\mathrm{B}$, respectively, in this study. However, others have

Table 4. Genotypes of analyzed SNP in the leptin $(L E P)$, leptin receptor $(L E P R)$, and acyl-coenzyme A:diacylglycerol acyltransferase 1 (DGAT1) genes, as well as genotypes for $\beta$-LG, $\beta$-CN, and $\kappa-\mathrm{CN}$ for the studied cows ${ }^{1}$

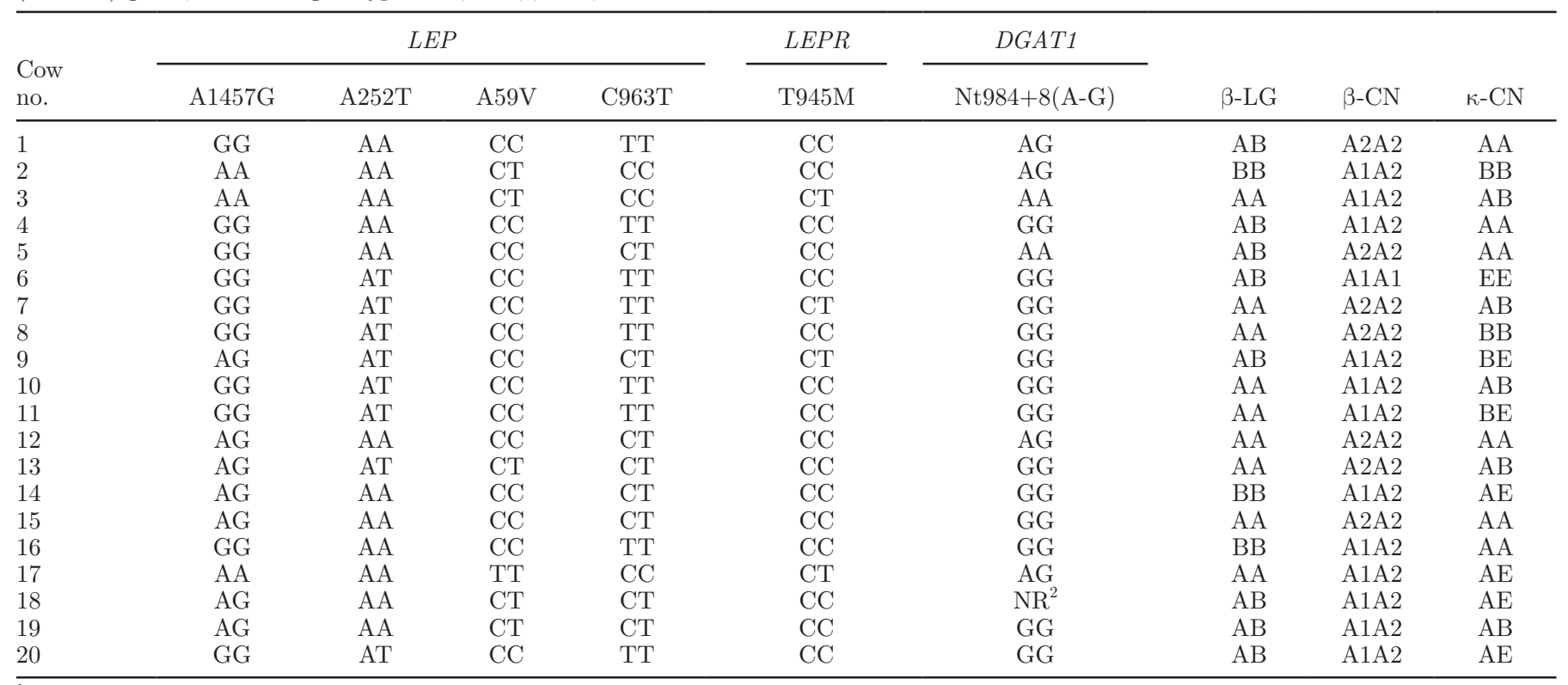

${ }^{1}$ For the $L E P, L E P R$, and $D G A T 1$ genes: $\mathrm{A}=$ adenine, $\mathrm{G}=$ guanine, $\mathrm{T}=$ thymine, $\mathrm{C}=$ cytosine.

${ }^{2}$ Not registered. 
Table 5. The Pearson correlation coefficient between technological properties and milk composition traits measured on milk samples from Swedish Red and Swedish Holstein cows $(\mathrm{df}=19)^{1}$

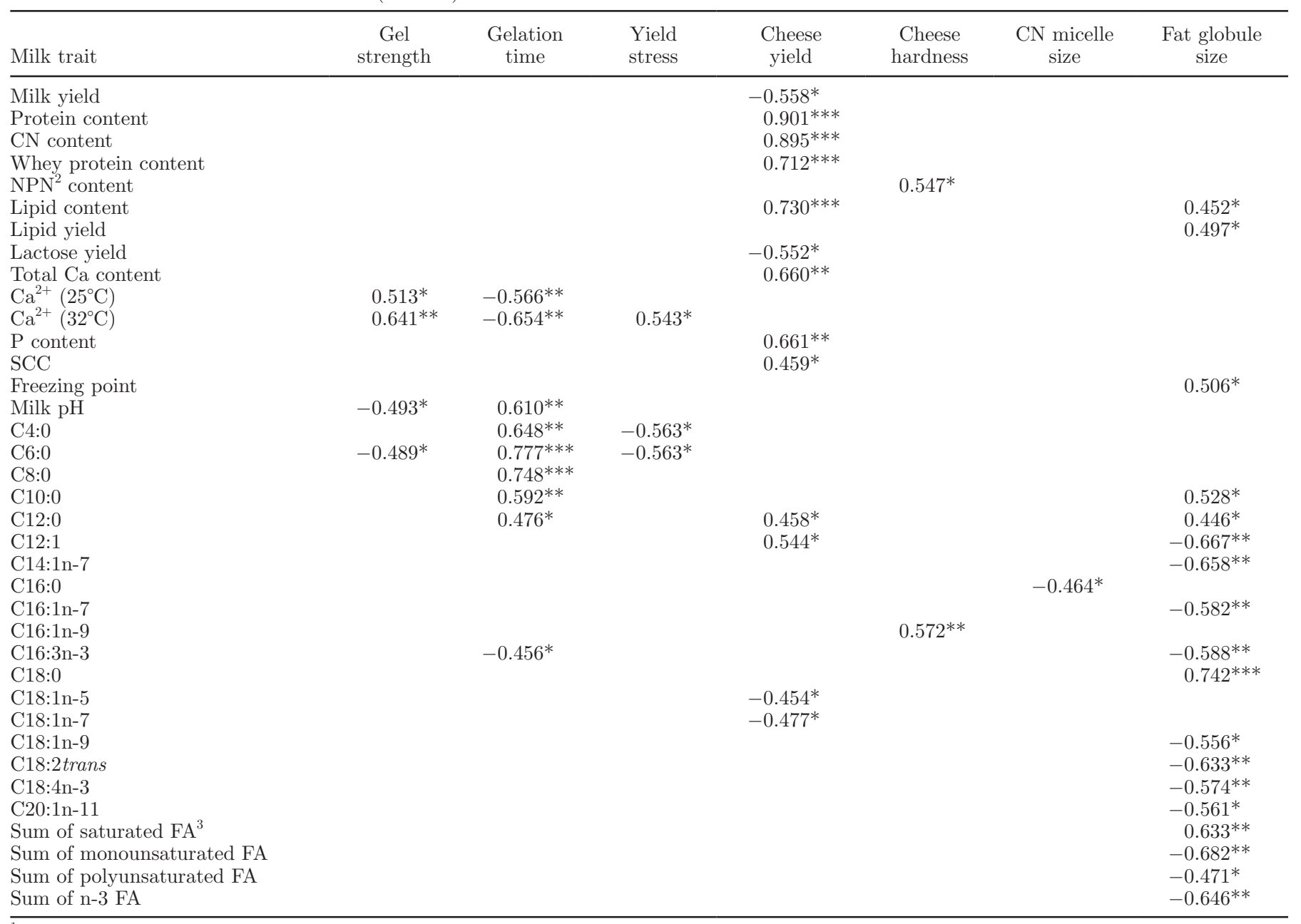

${ }^{1}$ Results are shown only for components correlated significantly $(P<0.05)$ with at least one property.

${ }^{2}$ Non-protein N.

${ }^{3} \mathrm{FA}=$ fatty acid.

${ }^{*} P<0.05 ;{ }^{* *} P<0.01 ;{ }^{* * *} P<0.001$.

reported on poor gelation properties for the $\mathrm{E}$ variant (Ikonen et al., 1999; Wedholm et al., 2006; Hallén et al., 2007).

As mentioned earlier, a favorable effect was found for the $\mathrm{T}$ allele of both $\mathrm{LEPR}_{\mathrm{T} 945 \mathrm{M}}$ and $\mathrm{LEP}_{\mathrm{A} 252 \mathrm{~T}}$ on gel strength (Table 2). Because of the small number of cows included in this study, these effects could depend on the $\mathrm{k}-\mathrm{CN} \mathrm{B}$ allele. However, cows having the $\mathrm{T}$ allele of $\mathrm{LEPR}_{\mathrm{T} 945 \mathrm{M}}$ were not homozygous for $\kappa-\mathrm{CN} \mathrm{B}$ and only one cow with the $\mathrm{T}$ allele of $\mathrm{LEP}_{\mathrm{A} 252 \mathrm{~T}}$ had the $\mathrm{BB}$ genotype of $\kappa-\mathrm{CN}$ (Table 4). Hence, such a bias may be neglected. The same may be applied for the favorable effect of $\beta$-LG A on gelation properties (Table 3), but once again, only one cow having the A allele of $\beta$-LG was homozygous for $\kappa-\mathrm{CN} \mathrm{B}$ (Table 4). In addition, a multigene model including alleles of $\beta-\mathrm{LG}, \beta-\mathrm{CN}$, and
$\kappa-\mathrm{CN}$ was used in the statistical evaluation of the genetic variants of milk proteins to exclude such a bias.

\section{Effect of Milk Composition on Technological Properties}

Milk composition is crucial for the technological properties during cheese production (Wedholm et al., 2006; Amenu and Deeth, 2007; Glantz et al., 2010) and should, therefore, be considered in the statistical models. However, results are often contradictory, making it difficult to decide which compositional parameters to include in the models. Data on milk composition traits found in these samples (our unpublished data) were, therefore, correlated with the analyzed technological properties and the results are presented in Table 5 . 
Table 6. Effects of $\beta$-CN, leptin $(L E P)$, leptin receptor $(L E P R)$, and $\beta$-LG alleles on technological properties of milk when including milk composition traits as covariates in the statistical model ${ }^{1}$

\begin{tabular}{|c|c|c|c|}
\hline Item & & & $P$-value \\
\hline $\begin{array}{l}\text { With all correlated comp } \\
\beta \text {-CN }\end{array}$ & A1 & $\mathrm{A} 2$ & \\
\hline Cheese yield $(\%)$ & $7.6 \pm 0.0$ & $7.5 \pm 0.0$ & 0.026 \\
\hline \multicolumn{4}{|c|}{ With all correlated milk composition traits except fatty acids as covariates ${ }^{2}$} \\
\hline $\mathrm{LEPR}_{\mathrm{T} 945 \mathrm{M}}$ & $\mathrm{C}$ & $\mathrm{T}$ & \\
\hline Cheese yield $(\%)$ & $7.3 \pm 0.1$ & $6.9 \pm 0.2$ & 0.022 \\
\hline$\beta-\mathrm{LG}$ & $\mathrm{A}$ & $\mathrm{B}$ & \\
\hline
\end{tabular}

\footnotetext{
${ }^{1}$ Values are expressed as least squares means \pm standard error. Results are shown only for properties with $P<0.10$.

${ }^{2}$ The covariates chosen are based on the correlations presented in Table 5 . For each technological property, the compositional traits that were found to correlate with that property were included in the statistical model as covariates.
}

Results are shown only for components that correlated significantly $(P<0.05)$ with at least one property. Once again, the results demonstrate that milk composition traits affected all of the analyzed technological properties, except cheese $\mathrm{pH}$. Thus, for each technological property, all of the compositional traits that were found to affect that property in this study were included in the statistical models as covariates. The results of effects of polymorphisms in the $L E P, L E P R$, and DGAT1 genes, as well as genetic variants of the analyzed milk protein genes, on technological properties, when compositional traits were included in the statistical models as covariates, are presented in Table 6 . Results are shown only for (1) SNP and proteins that had an effect $(P<0.10)$ on at least one technological property and $(2)$ properties that were significantly $(P$ $<0.10$ ) influenced by the studied SNP and milk protein genes. As can be derived from Table 6 , only $\beta$-CN had an effect on technological properties when all compositional traits were included in the model as covariates. The results indicate that the A1 variant of $\beta-\mathrm{CN}$ was associated with higher cheese yield than the $\mathrm{A} 2$ variant, which is in accordance with previous studies (Marziali and Ng-Kwai-Hang, 1986a,c). In this study, however, milk was defatted before rheological measurements and cheese making to decrease the number of variables influencing the results. Despite this, correlations were obtained between FA and gel strength, gelation time, yield stress, cheese yield, as well as cheese hardness, and between lipid content and cheese yield (Table 5). The same observation has previously been made in cheeses (Wedholm et al., 2006) and acidified gels (Allmere et al., 1999). If the FA were excluded as covariates in the statistical models, new associations were found (Table 6). The results show that the A allele of $\mathrm{LEP}_{\mathrm{A} 1457 \mathrm{G}}$ was associated with larger fat globules than the $\mathrm{G}$ allele, whereas the $\mathrm{C}$ allele of $\mathrm{LEPR}_{\mathrm{T} 945 \mathrm{M}}$ was shown to increase cheese yield compared with the $\mathrm{T}$ allele. In this case, the observation made for $\mathrm{LEPR}_{\mathrm{T} 945 \mathrm{M}}$ is contradictory to the results obtained when compositional traits were neglected in the statistical model, showing a favorable effect of the $\mathrm{T}$ allele on cheese characteristics (Table 2 ). This might be due to the limited material used in this study. Furthermore, $\beta$-LG was shown to have an effect on gelation time $(\mathrm{A}<\mathrm{B})$, which is in agreement with our results when compositional traits were not included in the model (Table 3). Also cheese yield (B > A) was shown to be affected by $\beta-L G$, which is in accordance with earlier studies (Jakob and Puhan, 1992; Ng-Kwai-Hang, 1998; Wedholm et al., 2006). Thus, it is striking what impact milk composition has on gene effects on technological properties, and hence, this is of the utmost importance to consider before a breeding program is implemented.

\section{CONCLUSIONS}

This study has demonstrated gene effects on technological properties important for cheese production. Today, no such information is used within the Nordic breeding work and, hence, the results show possibilities to optimize cheese quality in genetic selection programs. However, milk is a complex system and several factors influence the technological properties. Numerous studies have been carried out on the effects of genetic polymorphisms of milk proteins on technological properties, but yet the results are inconsistent. This may certainly 
be due to the conflicting results of the influence of milk composition on technological properties, but also the choice of statistical models used in the analyses. The same may be applied to other genes as well. Thus, considering the economic importance for the breeding and dairy industries, it is necessary to thoroughly assess the different aspects regarding the influence of gene effects on cheese characteristics before directly selecting for certain alleles or genetic variants to improve the processing and quality of cheese.

\section{ACKNOWLEDGMENTS}

The authors thank Laure Bourgeois at the Department of Food Technology, Engineering and Nutrition, Lund University, Sweden, for her help with the experimental work, Petr Dejmek of the same department for valuable discussions, and the staff at Nötcenter Viken (Falköping, Sweden) for valuable help during milking. Sparbanksstiftelsen Färs \& Frosta (Sjöbo, Sweden) and the Swedish Farmers' Foundation for Agricultural Research (SLF, Stockholm, Sweden) are gratefully acknowledged for financial support.

\section{REFERENCES}

Allmere, T., M. Åkerlind, and A. Andrén. 1999. Rheological properties of acidified gels of skim milk from cows selected for high or low milk fat concentration. Int. Dairy J. 9:703-707.

Amenu, B., and H. C. Deeth. 2007. The impact of milk composition on Cheddar cheese manufacture. Aust. J. Dairy Technol. 62:171-184.

Andrén, A. 2007. Influence of genetic milk protein variants on milk quality. J. Anim. Feed Sci. 16:143-150.

Banos, G., J. A. Woolliams, B. W. Woodward, A. B. Forbes, and M. P. Coffey. 2008. Impact of single nucleotide polymorphisms in leptin, leptin receptor, growth hormone receptor, and diacylglycerol acyltransferase (DGAT1) gene loci on milk production, feed, and body energy traits of UK dairy cows. J. Dairy Sci. 91:3190-3200.

Barbosa da Silva, M. V. G., T. S. Sonstegard, R. M. Thallman, E. E. Connor, R. D. Schnabel, and C. P. Van Tassell. 2010. Characterization of DGAT1 allelic effects in a sample of North American Holstein cattle. Anim. Biotechnol. 21:88-99.

Bonfatti, V., G. Di Martino, A. Cecchinato, L. Degano, and P. Carnier. 2010. Effects of $\beta$ - $\kappa$-casein (CSN2-CSN3) haplotypes, $\beta$-lactoglobulin $(B L G)$ genotypes, and detailed protein composition on coagulation properties of individual milk of Simmental cows. J. Dairy Sci. 93:3809-3817.

Bovenhuis, H., J. A. M. Van Arendonk, and S. Korver. 1992. Associations between milk protein polymorphisms and milk production traits. J. Dairy Sci. 75:2549-2559.

Buchberger, J., and P. Dovč. 2000. Lactoprotein genetic variants in cattle and cheese making ability. Food Technol. Biotechnol. 38:91-98.

Choi, J. 1996. Effects of genetic variants of kappa-casein beta-lactoglobulin and heat treatments on cheese yielding capacity, cheese composition and coagulation properties of milk. MSc Thesis. McGill University, Montreal, Canada.

Devold, T. G., M. J. Brovold, T. Langsrud, and G. E. Vegarud. 2000. Size of native and heated casein micelles, content of protein and minerals in milk from Norwegian Red Cattle - Effect of milk protein polymorphism and different feeding regimes. Int. Dairy J. 10:313-323.
Dimitreli, G., and A. S. Thomareis. 2007. Texture evaluation of blocktype processed cheese as a function of chemical composition and in relation to its apparent viscosity. J. Food Eng. 79:1364-1373.

Edwards, P. B., L. K. Creamer, and G. B. Jameson. 2009. Structure and stability of whey proteins. Pages $163-203$ in Milk Proteins: From Expression to Food. A. Thompson, M. Boland, and H. Singh, ed. Elsevier Inc., Burlington, MA.

Elofsson, U. M., M. A. Paulsson, P. Sellers, and T. Arnebrant. 1996. Adsorption during heat treatment related to the thermal unfolding/aggregation of beta-lactoglobulins A and B. J. Colloid Interface Sci. 183:408-415.

Glantz, M., T. G. Devold, G. E. Vegarud, H. Lindmark Månsson, H. Stålhammar, and M. Paulsson. 2010. Importance of casein micelle size and milk composition for milk gelation. J. Dairy Sci. 93:1444-1451.

Glantz, M., H. Lindmark Månsson, H. Stålhammar, L.-O. Bårström, M. Fröjelin, A. Knutsson, C. Teluk, and M. Paulsson. 2009. Effects of animal selection on milk composition and processability. J. Dairy Sci. 92:4589-4603.

Hallén, E., T. Allmere, J. Näslund, A. Andrén, and A. Lundén. 2007. Effect of genetic polymorphism of milk proteins on rheology of chymosin-induced milk gels. Int. Dairy J. 17:791-799.

Ikonen, T., K. Ahlfors, R. Kempe, M. Ojala, and O. Ruottinen. 1999. Genetic parameters for the milk coagulation properties and prevalence of noncoagulating milk in Finnish dairy cows. J. Dairy Sci. $82: 205-214$.

Ikonen, T., M. Ojala, and E. L. Syväoja. 1997. Effects of composite casein and beta-lactoglobulin genotypes on renneting properties and composition of bovine milk by assuming an animal model. Agric. Food Sci. Finland 6:283-294.

International Dairy Federation. 2010. The world dairy situation 2010. Bulletin 446/2010. International Dairy Federation, Brussels, Belgium.

Jakob, E., and Z. Puhan. 1992. Technological properties of milk as influenced by genetic polymorphism of milk proteins - A review. Int. Dairy J. 2:157-178.

Jenness, R., and J. Koops. 1962. Preparation and properties of a salt solution which simulates milk ultrafiltrate. Neth. Milk Dairy J. $16: 153-164$.

Komisarek, J., and Z. Dorynek. 2006. The relationship between the T945M single nucleotide polymorphism in the leptin receptor gene $(L E P R)$ and milk production traits in Jersey cows. Anim. Sci. Pap. Rep. 24:271-277.

Kübarsepp, I., M. Henno, H. Viinalass, and D. Sabre. 2005. Effect of kappa-casein and beta-lactoglobulin genotypes on the milk rennet coagulation properties. Agron. Res. 3:55-64.

Lodes, A., J. Buchberger, I. Krause, J. Aumann, and H. Klostermeyer. 1996. The influence of genetic variants of milk proteins on the compositional and technological properties of milk. 2. Rennet coagulation time and firmness of the rennet curd. Milchwissenschaft 51:543-548.

Lucey, J. A., T. van Vliet, K. Grolle, T. Geurts, and P. Walstra. 1997. Properties of acid casein gels made by acidification with glucono- $\delta$ lactone. 1. Rheological properties. Int. Dairy J. 7:381-388.

Marziali, A. S., and K. F. Ng-Kwai-Hang. 1986a. Effects of milk composition and genetic polymorphism on cheese composition. J. Dairy Sci. 69:2533-2542.

Marziali, A. S., and K. F. Ng-Kwai-Hang. 1986b. Effects of milk composition and genetic polymorphism on coagulation properties of milk. J. Dairy Sci. 69:1793-1798.

Marziali, A. S., and K. F. Ng-Kwai-Hang. 1986c. Relationships between milk protein polymorphisms and cheese yielding capacity. J. Dairy Sci. 69:1193-1201.

Ng-Kwai-Hang, K. F. 1998. Genetic polymorphism of milk proteins: Relationships with production traits, milk composition and technological properties. Can. J. Anim. Sci. 78:131-147.

Pagnacco, G., and A. Caroli. 1987. Effect of casein and beta-lactoglobulin genotypes on renneting properties of milks. J. Dairy Res. $54: 479-485$. 
Rehn, U., M. A. Petersen, K. Hallin Saedén, and Y. Ardö. 2010. Ripening of extra-hard cheese made with mesophilic DL-starter. Int. Dairy J. 20:844-851.

Schennink, A., W. M. Stoop, M. H. P. W. Visker, J. M. L. Heck, H Bovenhuis, J. J. van der Poel, H. J. F. van Valenberg, and J. A. M. van Arendonk. 2007. DGAT1 underlies large genetic variation in milk-fat composition of dairy cows. Anim. Genet. 38:467-473.

Tsioulpas, A., M. J. Lewis, and A. S. Grandison. 2007. Effect of minerals on casein micelle stability of cow's milk. J. Dairy Res. $74: 167-173$.
Walstra, P., T. J. Geurts, A. Noomen, A. Jellema, and M. A. J. S. van Boekel. 1999. Dairy Technology: Principles of Milk Properties and Processes. Marcel Dekker Inc., New York, NY.

Wedholm, A., L. B. Larsen, H. Lindmark Månsson, A. H. Karlsson, and A. Andrén. 2006. Effect of protein composition on the cheesemaking properties of milk from individual dairy cows. J. Dairy Sci. 89:3296-3305. 